\title{
Gambaran Umum, Prevalensi, dan Pencegahan Antraks pada Manusia di Indonesia
}

\section{General Description, Prevalence, and Prevention of Human Anthrax in Indonesia}

\author{
Ihda Zuyina Ratna Sari*, Silvia Apriliana \\ Balai Penelitian dan Pengembangan Kesehatan Banjarnegara, Badan Litbang Kesehatan, \\ Kementerian Kesehatan RI \\ Jalan Selamanik No.16 A Banjarnegara, Jawa Tengah, Indonesia \\ *E_mail: ihda.zuyina.r@gmail.com
}

Received date: 25-06-2020, Revised date: 28-08-2020, Accepted date: 11-11-2020

\begin{abstract}
ABSTRAK
Antraks merupakan neglected zoonotic disease yang masih menjadi isu global karena dapat menyebabkan epidemi reguler. Antraks tidak hanya memberikan pengaruh pada aspek kesehatan tetapi juga aspek sosialekonomi, keamanan, dan kesejahteraan masyarakat. Tujuan dari penulisan narrative review ini yaitu untuk memberikan gambaran umum mengenai antraks pada manusia, prevalensi, dan pencegahannya di Indonesia. Penelusuran literatur dilakukan dengan menggunakan peramban seperti Google scholar, Crossref, Mendeley, PLos One, Elsevier, dan website resmi Kementerian Kesehatan. Pembatasan literatur yang digunakan yaitu diterbitkan antara tahun 2015-2020. Antraks disebabkan bakteri Bacillus antrachis yang dapat menginfeksi ternak maupun manusia. Virulensi bakteri antraks ditentukan oleh kompleks toksin tripartite dan kapsul asam poli- $\gamma$-D-glutamat. Antraks pada manusia dapat dijumpai dalam empat bentuk utama yaitu kutaneus, gastrointestinal, inhalasi, dan injeksi. Setiap bentuk berpotensi mengalami komplikasi menjadi antraks meningitis dan sepsis. Pengobatan antraks umumnya dilakukan dengan terapi antibiotik. Di Indonesia sebanyak 14 provinsi dinyatakan sebagai daerah endemik antraks. Prevalensi antraks pada manusia di Indonesia bersifat fluktuatif dan sebagian besar merupakan antraks kutaneus. Pencegahan dan pengendalian antraks dapat dilakukan terutama dengan vaksinasi, mematuhi aturan/SOP dari instansi berwenang, kerjasama multisektor, penguatan surveilans antraks, peningkatan kapasitas sumber daya untuk diagnosis, dan peningkatan pengetahuan serta kesadaran masyarakat.
\end{abstract}

Kata kunci: antraks, Indonesia, prevalensi, penyakit zoonosis

\begin{abstract}
Anthrax is a neglected zoonotic disease that remains a global issue because it can cause regular epidemics. Anthrax affects not only health systems but also social-economic conditions, safety, and welfare of the people. This paper aimed to give an overview of human anthrax, prevalence, and prevention in Indonesia. A literature search was performed using search engines such as Google Scholar, Crossref, Mendeley, PLoS One, Elsevier, dan the Ministry of Health official website. The literature used were published between 2015-2020. Anthrax is caused by Bacillus anthracis that affects animals and humans. The virulence factors of these bacteria are determined by the tripartite toxin complex and poly- $\gamma$-D-glutamic acid capsule. Anthrax in humans can be found in four forms, namely cutaneous, gastrointestinal, inhalational, and injection anthrax. Each form of anthrax can develop into meningitis and sepsis. Anthrax treatment is commonly done by administering antibiotics. In Indonesia, 14 provinces have been declared anthrax endemic areas. The prevalence of human anthrax in Indonesia is fluctuating and most of it is cutaneous anthrax. Prevention and control of anthrax can be done mainly by vaccination, obeying the rules or standard operating procedures of the authorities, multisectoral cooperation, strengthening anthrax surveillance, increasing resources for diagnosis, increasing public knowledge, and awareness.
\end{abstract}

Keywords: anthrax, Indonesia, prevalence, zoonotic disease 


\section{PENDAHULUAN}

Zoonosis merupakan penyakit yang mempengaruhi populasi hewan maupun manusia. ${ }^{1}$ Zoonosis tidak hanya memberikan dampak pada sistem kesehatan manusia dan hewan tetapi juga pada kondisi sosialekonomi, keamanan, dan kesejahteraan masyarakat. ${ }^{1,2}$

Antraks merupakan salah satu penyakit zoonosis terabaikan (neglected zoonotic disease) yang masih menjadi isu global. ${ }^{3-5}$ Antraks secara umum dapat menginfeksi semua hewan homoioterm (berdarah panas) termasuk manusia. ${ }^{6}$ Antraks disebabkan bakteri Bacillus antrachis yang dapat membentuk spora. ${ }^{7}$ Spora antraks dapat bertahan hingga ratusan tahun di tanah karena relatif tahan pada kondisi lingkungan yang ekstrim dan sulit dimatikan dengan disinfektan biasa. $^{7-9}$

Persistensi spora antraks di lingkungan tersebut dapat menyebabkan terjadinya epidemi reguler. Di Swedia antraks kembali terjadi setelah 27 tahun tidak terjadi kasus. ${ }^{7}$ Antraks juga menjadi perhatian dunia karena spora antraks mempunyai potensi untuk digunakan sebagai senjata biologi atau bioterorisme dengan tingkat kematian yang tinggi. ${ }^{8,10,11}$ Bakteri antraks dapat menginfeksi dan menyebabkan kematian pada mamalia liar maupun ternak (terutama herbivora seperti sapi dan domba), beberapa jenis unggas, dan manusia. $^{7-9}$ Antraks termasuk penyakit infeksi non-contagious yaitu tidak menular antar hewan maupun antar manusia. ${ }^{12}$

Kematian akibat antraks pada manusia pernah dilaporkan di beberapa provinsi di Indonesia (terutama provinsi yang merupakan endemik antraks). ${ }^{13}$ Antraks bersifat enzootik dan termasuk re-emerging disease atau penyakit yang dapat berulang dan tingkat kematian tinggi akibat antraks pada manusia umumnya disebabkan karena tidak terdiagnosis dan tidak tepatnya pengobatan yang dilakukan. ${ }^{8,14,15}$

Kementerian

Kesehatan RI

mengklasifikasikan antraks pada manusia berdasarkan gejala klinisnya menjadi 4 bentuk yaitu antraks kulit (paling sering terjadi), antraks saluran pernafasan, antraks paru-paru, dan antraks meningitis. ${ }^{16}$ Infeksi antraks umumnya melalui kontak langsung antara kulit atau membran mukosa dengan spora $B$. antrachis (ketika menyembelih, memproses bagian, atau kontak dengan produk hewan terinfeksi), mengonsumsi daging hewan terinfeksi, dan menghirup spora antraks. ${ }^{7,8,12}$ Infeksi antraks pada manusia umumnya mempunyai korelasi dengan kejadian antraks yang terjadi pada hewan ternak/peliharaan, di negara-negera maju yang telah mampu mengendalikan antraks pada hewan mempunyai tingkat infeksi antraks pada manusia sangat kecil yaitu hewan/manusia 10/1, sedangkan tingkat infeksi antraks di negara berkembang dapat lebih tinggi mencapai 1/10. ${ }^{14}$ Hal tersebut disebabkan kemiskinan dan pelayanan kesehatan hewan yang tidak memadai. ${ }^{14}$

Antraks masih menjadi ancaman kesehatan bagi masyarakat di Afrika, Timur Tengah, Amerika Selatan, Asia Tengah, dan Asia meskipun secara global telah terjadi penurunan kasus pada manusia maupun hewan. ${ }^{11,17}$ Hasil studi retrospektif yang dilakukan oleh Mwakapeje et al di beberapa distrik wilayah Arushia dan Klimanjoro (Tanzania) menunjukkan sebanyak 330 kasus antraks pada manusia, 103 kasus antraks pada ternak, dan 18 kasus antraks pada hewan liar telah dilaporkan selama tahun 2006-2016. ${ }^{9}$ Wabah antraks juga dilaporkan di Nakuru (Kenya) antara tahun 2014-2017, sebanyak 15 dari 71 orang menderita antraks setelah kontak dengan ternak terinfeksi dimana tujuh orang menderita antraks gastrointestinal, enam orang menderita antraks kutaneus, dan dua orang menderita antraks oropharyngeal. ${ }^{18}$ Pada Agustus 2017 juga dilaporkan adanya wabah antraks gastrointestinal di Uganda dimana lebih dari 40 orang mengalami gastroenteritis akut setelah mengonsumsi daging sapi terinfeksi antraks dari seorang penjagal. ${ }^{19}$ Pada tahun 2018 dilaporkan dua kasus antraks kutaneus di Provinsi Shaanxi (China) dimana 
infeksi diduga berasal dari sapi yang tidak divaksinasi antraks. ${ }^{17}$

Kasus antraks di seluruh dunia diperkirakan berkisar 20.000-100.000 per tahun, sedangkan antraks pada manusia berkisar 2.000-20.000 orang pertahun., 2,179 Antraks masih sering terjadi di negara kurang berkembang dan berkembang meskipun telah dilakukan penelitian berkelanjutan dan berbagai langkah pengendalian. ${ }^{4}$ Antraks terutama terjadi pada komunitas pertanian yang berada di daerah beriklim tropis dengan kondisi sosial ekonomi yang buruk. ${ }^{11}$ Terjadinya antraks pada suatu daerah dapat menyebabkan permasalahan masyarakat karena tidak hanya berdampak pada kesehatan tetapi juga pada perekonomian masyarakat terutama yang bergantung pada peternakan pastoral. 811,12 Antraks memberikan dampak ekonomi yang signifikan karena menurunkan produktivitas dengan mengurangi efisiensi input (sumber daya) yang akan dikonversi menjadi output (produk). ${ }^{3}$ Antraks ditetapkan sebagai salah satu dari 25 jenis penyakit yang menyebabkan kematian tinggi pada hewan, menimbulkan kerugian ekonomi, dan menyebabkan keresahan masyarakat berdasarkan Keputusan Menteri Pertanian Nomor 4026/Kpts./OT.140/3/2013 tentang Penetapan Jenis Penyakit Hewan Menular Strategis. ${ }^{12}$

Pencegahan dan pengendalian perlu dilakukan untuk meminimalisir terjadinya kasus antraks terutama pada manusia, saat ini pencegahan dan pengendalian terutama dilakukan dengan vaksinasi ternak dan respon cepat jika terjadi wabah untuk membatasi terjadinya kontaminasi lingkungan dan paparan pada manusia. ${ }^{89}$ Penulisan narrative review ini bertujuan untuk memberikan gambaran umum mengenai antraks pada manusia, prevalensi, dan pencegahannya di Indonesia. Tulisan ini secara khusus membahas agen penyebab, diagnosis, mekanisme infeksi, faktor risiko, gambaran klinis dan pengobatan, prevalensi, pencegahan, serta pengendalian antraks pada manusia terutama di Indonesia.

\section{METODE}

Tulisan ini merupakan hasil studi pustaka dari berbagai literatur dalam bentuk jurnal penelitian, review, pedoman/petunjuk teknis, peraturan perundangan, dan artikel ilmiah terkait dengan antraks khususnya pada manusia. Penelusuran literatur dilakukan dengan berbagai peramban seperti Google scholar, Crossref, Mendeley, PLos One, Elsevier, dan website resmi Kementerian Kesehatan.

Jumlah literatur yang ditemukan dari hasil penelusuran yaitu sebanyak 138 artikel. Literatur tersebut kemudian diseleksi berdasarkan topik yang terkait dengan epidemiologi antraks secara umum (agen, diagnosis, mekanisme infeksi, faktor risiko, gambaran klinis, dan pengobatan), prevalensi, dan pencegahan antraks pada manusia terutama di Indonesia. Pembatasan literatur yang digunakan juga dilakukan yaitu diterbitkan antara tahun 2015-2020. Berdasarkan hasil seleksi diperoleh 44 artikel yang sesuai. Hasil studi pustaka kemudian disajikan secara deskriptif berdasarkan literatur yang diperoleh.

\section{PEMBAHASAN}

\section{Agen dan Diagnosis Antraks}

Antraks disebabkan oleh bakteri patogenik dari famili Bacillaceae yaitu Bacillus antrachis. ${ }^{8,20,21}$ Bacillus antrachis termasuk bakteri gram positif yang mempunyai karakteristik berbentuk basil (batang), bersifat nonmotil dan nonhemolitik, dapat hidup secara aerobik atau anaerobik fakultatif, dapat membentuk kapsul, serta dapat menghasilkan toksin yang menentukan tingkat virulensi bakteri tersebut., ${ }^{7,14,22}$ Bakteri antraks dapat dijumpai dalam dua bentuk yaitu sel vegetatif (berukuran sekitar $4 \times 11 \mu \mathrm{m}$ ) dan spora (berukuran sekitar $2 \times 1 \mu \mathrm{m}) .{ }^{17,23}$ Bacillus antrachis termasuk bakteri yang relatif homogen (tingkat polimorfisme rendah), hal tersebut kemungkinan disebabkan oleh siklus hidupnya yang lama sebagai endospora aktif. ${ }^{4}$

Bakteri antraks dapat tumbuh cepat pada temperatur $35-37^{\circ} \mathrm{C}$ di dalam darah atau 
nutrien agar dan pada kondisi aerobik atau anaerobik. ${ }^{3}$ Karakter morfologi koloni $B$. antrachis yaitu berbentuk lebar, datar, nonhemolitik, lengket, warna bervariasi dari putih hingga abu-abu, diameter $2-5 \mathrm{~mm}$, tepi koloni tidak beraturan, dan mempunyai morfologi khas yang disebut kepala medusa (medusa head). ${ }^{14}$ Konfirmasi B. antrachis dengan uji laboratorium dilakukan dengan melihat pembentukan kapsul bakteri secara in vitro pada kondisi ketersediaan karbondioksida (5-20\%) dan bikarbonat serta melihat kepekaan bakteri terhadap lytic gamma bacteriophage (bakteriofag gamma litik). ${ }^{3,14,24}$

Tingkat virulensi $B$. antrachis ditentukan oleh dua faktor utama yaitu kompleks toksin tripartite dan kapsul asam poli- $\gamma$-D-glutamat. ${ }^{25}$ Kompleks toksin tersebut terdiri dari Protective Antigen (PA), Lethal Factor (LF), dan Edema Factor (EF). ${ }^{14}$ Protective Antigen dan $\mathrm{EF}$ bergabung membentuk Edema Toxin (EdTx), sedangkan PA dan LF bergabung membentuk Lethal Toxin (LeTx). ${ }^{14,25,26}$ Toksin disekresikan selama pembelahan sel vegetatif $B$. antrachis dan menjadi penyebab munculnya tanda dan gejala khas antraks. ${ }^{14}$ Lethal Factor dapat menghambat mitogen-activated protein kinase yang mengarah ke apoptosis makrofag dan dianggap sebagai penyebab utama keparahan penyakit serta kematian akibat antraks, EF meningkatkan level cyclic adenosine monophosphate pada sel yang rentan dan menyebabkan perubahan homeostasis air serta edema. ${ }^{14,26}$ Toksin B. antrachis dapat merusak pembuluh darah yang menyebabkan kebocoran cairan. ${ }^{27}$ Kebocoran juga dapat terjadi pada pembuluh kecil yang dapat memicu terjadinya syok dan kematian pada hewan. ${ }^{27}$ Kapsul asam poli- $\gamma$-D-glutamat berfungsi melindungi bakteri antraks dari fagositosis dan pengawasan sistem imun dengan mekanisme yang mirip dengan bakteri patogenik lainnya. ${ }^{15}$ Beberapa faktor diketahui juga berkontribusi terhadap tingkat virulensi $B$. antrachis yaitu cell surface protein EAI dan Sap, anthrolysin $O$, siderophores, dan metal cation transport proteins. ${ }^{14}$
Sel vegetatif antraks relatif rentan atau mempunyai kemampuan bertahan hidup yang rendah di sebagian besar kondisi lingkungan, sedangkan bentuk spora lebih resisten. ${ }^{14}$ Spora akan terbentuk ketika bakteri keluar dari tubuh manusia maupun hewan (inang). ${ }^{10,14}$ Spora antraks tahan terhadap berbagai kondisi ekstrim seperti panas, dingin, hujan, kekeringan, tekanan, sinar ultraviolet, radiasi, dan senyawa kimia, selain itu tidak rentan antibiotik, dan sulit dimatikan dengan disinfektan biasa. ${ }^{9,14,27}$ Laju pembentukan spora dari sel vegetatif dipengaruhi oleh kondisi lingkungan seperti suhu, kelembaban, aktivitas air, $\mathrm{pH}$, ketersediaan oksigen, cahaya, $\mathrm{Mn}^{2+}$, serta ketersediaan nutrien. ${ }^{14}$ Kondisi lingkungan yang mungkin dapat memicu germinasi, multiplikasi, atau resporulasi spora antraks di luar tubuh inang yaitu suhu berkisar $8-45^{\circ} \mathrm{C}$, pH 5-9, kelembaban udara lebih dari $95 \%$, dan adanya nutrien yang mencukupi. ${ }^{7}$ Spora antraks akan melakukan germinasi pada lingkungan yang kaya akan asam amino, nukleosida, dan glukosa, kemudian akan membentuk spora kembali ketika sumber nutrien habis. ${ }^{14}$ Kandungan humus dalam tanah berkisar 2,1-5,5\% diketahui berkontribusi terhadap kelangsungan hidup agen infeksi termasuk spora antraks. ${ }^{22}$ Spora antraks juga dapat bertahan lama di tanah terutama dengan kondisi kation kalsium tinggi, lembab, $\mathrm{pH}$ netral, atau cenderung basa. ${ }^{27}$ Ketersediaan senyawa organik di dalam tanah akan mempengaruhi adesi spora, sedangkan, kation kalsium dan level $\mathrm{pH}$ berperan penting dalam proses germinasi dan pertahanan viabilitas spora antraks. ${ }^{23}$ Daerah dataran rendah yang panas merupakan tempat yang sesuai untuk pembentukan spora dan proliferasi bakteri antraks, hal tersebut disebabkan spora antraks bersifat hidrofobik tinggi sehingga mudah terbawa air hujan bersamaan dengan zat organik tanah dan apabila terjadi penguapan di suatu daerah maka daerah tersebut dapat menjadi hotspot antraks. ${ }^{2,7}$

Metode yang umum digunakan untuk diagnosis antraks antara lain identifikasi gen, 
uji serologi (ELISA, Western Blot, Toxin Detection, Chromatographic Assay atau FAT) dan Ascole, sedangkan Office International des Epizooties (OIE) dan World Health Organization (WHO) merekomendasikan metode Lytic Gamma Phage, Immunochromatographic Assay, Direct Fluorescence Assay (DFA), dan Polymerase Chain Reaction (PCR). ${ }^{7,24}$ Polymerase Chain Reaction dinilai lebih cepat dan akurat serta dapat digunakan ketika ketersediaan bakteri dalam sampel sedikit. ${ }^{71}$ Reaksi ini dapat mendeteksi sekuens DNA (gen) spesifik yang dimiliki oleh bakteri antraks yaitu gen yang menyandi pembentukan toksin dan regulasinya (terdapat dalam plasmid pXO1) dan gen AcpA serta AcpB yang mengatur sintesis kapsul dan regulasinya (terdapat dalam plasmid pXO2). ${ }^{14,28}$ Diagnosis antraks juga dapat dilakukan dengan melihat deskripsi klinis, riwayat kontak sebelumnya dengan hewan atau produk hewan yang terinfeksi atau diduga terinfeksi antraks, serta adanya hasil positif kultur mikroorganisme dari darah dan cairan lesi. ${ }^{17}$ Diagnosis retrospektif juga dapat dilakukan dengan tes hipersensitivitas kulit menggunakan Anthraxin $\mathrm{T}^{24}$ Anthraxin $\mathrm{T}$ diduga juga berguna pada kasus-kasus yang tidak dapat dikonfirmasi melalui uji bakteriologis maupun uji serologis. ${ }^{29}$

\section{Mekanisme Infeksi dan Faktor Risiko Antraks pada Manusia}

Siklus infeksi diawali ketika ternak terinfeksi antraks, ternak terutama herbivora (sapi dan domba) sebagai inang primer umumnya terinfeksi spora $B$. antrachis ketika merumput atau memakan dedaunan yang terkontaminasi spora antraks. ${ }^{2,5,23}$ Bakteri antraks yang masuk ke dalam tubuh hewan bersamaan dengan makanan akan berkembangbiak di saluran cerna. ${ }^{30}$ Hewan terinfeksi kemudian akan mengeluarkan bakteri antraks bersamaan dengan feses, urin, atau kotoran lainnya. ${ }^{6}$ Selain itu, hewan terinfeksi antraks yang mati masih mengandung banyak bakteri antraks di dalam jaringannya yang kemudian akan berubah menjadi bentuk spora apabila bangkai hewan terbuka dan terekspos oksigen atau air., ${ }^{2,10}$ Spora antraks yang keluar dari tubuh hewan terinfeksi kemudian akan mencemari tanah, rumput, dan sumber air disekitarnya. ${ }^{22}$ Tanah atau area yang terkontaminasi dengan spora $B$. antrachis dikenal sebagai reservoir antraks. ${ }^{22}$ Manusia dapat terinfeksi antraks melalui beberapa rute dan umumnya disebabkan adanya interaksi dengan hewan terinfeksi, memakan atau memproses produk hewan yang terkontaminasi. ${ }^{23,31,32}$

Manusia dapat terinfeksi antraks melalui 4 rute utama yaitu inhalasi, gastrointestinal, kutaneus, dan intravena/ injeksi. ${ }^{3,15}$ Pada rute inhalasi, spora antraks yang ada di udara masuk melalui saluran pernafasan, pada rute gastrointestinal spora masuk melalui saluran pencernaan akibat mengonsumsi daging atau produk hewan terinfeksi antraks, sedangkan pada rute kutaneus, spora antraks masuk akibat adanya kontak langsung antara luka atau lesi pada kulit dengan ternak atau produk ternak terinfeksi antraks. ${ }^{12}$ Beberapa literatur menyebutkan gigitan serangga juga dapat menjadi media penularan antraks ke manusia. ${ }^{12,33}$ Spora antraks yang masuk ke dalam tubuh akan bergerminasi dengan cepat dan menghasilkan toksin dalam jumlah banyak. ${ }^{15}$ Toksin kemudian menyebar melalui aliran darah dan menyebabkan gejala klinis mulai dari edema dan nekrosis, sepsis, serta rusaknya pembuluh. ${ }^{15}$

Manusia yang mempunyai risiko tinggi terinfeksi antraks antara lain pekerja pengolah produk hewan (daging, kulit, rambut, tulang atau produk tulang, dan wol), dokter hewan dan petugas kesehatan hewan, pekerja peternakan dan pertanian terutama di daerah endemis antraks, rumah tangga atau peternak yang pernah mengalami kematian ternak dan mengonsumsi daging terkontaminasi spora antraks, pekerja laboratorium yang menangani sampel antraks, personel militer dan pekerja tanggap darurat yang menangani bioterorisme menggunakan spora antraks, serta pengguna heroin suntik. ${ }^{12,24,34}$ Selain itu, perilaku tidak 
menggunakan alas kaki ketika melakukan kegiatan di luar rumah terutama di sawah dan bermain meningkatkan risiko terinfeksi spora antraks. $^{2}$

\section{Bentuk Antraks pada Manusia dan Pengobatannya}

Antraks pada manusia dapat dibagi menjadi beberapa bentuk berdasarkan gejala klinis dan rute transmisinya yaitu antraks kulit (kutaneus), antraks tipe saluran pencernaan (gastrointestinal), antraks paru-paru (pulmonar/ inhalasi), dan antraks injeksi. ${ }^{19,35}$ Setiap bentuk antraks memiliki potensi untuk berkembang menjadi infeksi sistemik yang fatal seperti sepsis dan meningitis sebagai akibat dari penyebaran limfohematogen $B$. antrachis dari lesi primer antraks kutaneus, gastrointestinal, maupun inhalasi. ${ }^{14}$ Sebagian besar kasus antraks pada manusia merupakan antraks kutaneus (95\%) dan jarang berakibat fatal dengan pengobatan antibiotik. ${ }^{24,33}$ Tingkat fatalitas setiap bentuk antraks pada manusia berbeda-beda. ${ }^{12}$ Antraks kutaneus mempunyai tingkat fatalitas $20 \%$, antraks gastrointestinal $25-75 \%$, sedangkan antraks inhalasi mencapai $85-100 \% .^{7,12}$

Antraks kutaneus terjadi akibat spora antraks masuk ke dalam tubuh melalui luka/ lesi, abrasi kulit, atau gigitan serangga, dan lebih dari $90 \%$ lesi terjadi pada permukaan kulit yang terbuka seperti wajah, leher, lengan atau tangan, dan sering mencerminkan pekerjaan pasien. ${ }^{14}$ Pekerja yang membawa hewan atau produk hewan terinfeksi dengan bahu rentan terhadap infeksi di bagian belakang leher, pengolah produk hewan terkontaminasi cenderung terinfeksi di bagian lengan, pergelangan tangan, dan tangan. ${ }^{14,24}$ Masa inkubasi antraks kutaneus umumnya antara 1-7 hari dengan gejala awal muncul papula atau benjolan kecil mirip jerawat terasa gatal tetapi tidak menyebabkan nyeri dan mungkin akan dikelilingi oleh vesikel-vesikel kecil. ${ }^{24,34}$ Papula yang berada di tengah akan dengan cepat berubah bentuk menjadi vesikel atau bulla, mengalami ulserasi, mengering dan membentuk eschar atau bekas luka berbentuk cekung berwarna hitam yang merupakan tanda patognomonik antraks. ${ }^{29}$ Pada umumnya di sekitar lesi akan terjadi eritema dan edema serta dapat disertai adanya limfadenopati regional. ${ }^{24,29}$ Demam ringan, malaise, dan sakit kepala dapat muncul pada kasus-kasus yang berat. ${ }^{29,36}$ Penderita antraks kutaneus umumnya tidak perlu dirawat dan hanya berobat jalan kecuali terjadi infeksi sekunder yang ditandai dengan demam, bernanah, dan nyeri. ${ }^{16}$

Antraks gastrointestinal umumnya bersifat perakut atau akut dan terjadi akibat mengonsumsi daging atau produk hewan yang terinfeksi $B$. antrachis dalam kondisi tidak matang. ${ }^{19,24}$ Spora antraks dapat menginfeksi semua bagian saluran pencernaan terutama ileum dan kolon. ${ }^{29}$ Spora antraks yang masuk ke dalam sistem pencernaan akan mengalami germinasi dan dapat menyebabkan inflamasi serta terbentuknya lesi ulseratif di lokasi germinasi, sedangkan pada kasus yang parah dapat mengakibatkan pendarahan, obstruktif, atau perforasi. ${ }^{24,29}$ Masa inkubasi antraks gastrointestinal yaitu 1-6 hari dengan gejala awal demam, muntah, tidak nafsu makan, dan diikuti rasa sakit pada perut yang hebat. ${ }^{19,24}$ Antraks gastrointestinal dibagi menjadi 2 tipe yaitu abdominal dan oropharyngeal. ${ }^{14}$ Tipe abdominal ringan ditandai dengan malaise, demam ringan, mual, muntah, diare, dan anoreksia, sedangkan pada kasus yang berat ditandai dengan sakit perut parah, hematemesis, diare berdarah, asites masif, kemungkinan juga terjadi demam tinggi, dyspnea, sianosis, disorientasi, dan tanda septikemia lainnya. ${ }^{29}$ Kasus antraks abdominal yang berat juga dapat berkembang dengan cepat dan menyebabkan syok, koma, bahkan kematian. $^{29}$ Tipe oropharyngeal ditandai dengan sakit tenggorokan, disfagia, demam, suara serak, pembengkakan di daerah leher akibat edema dan limfadenopati servikal yang mengganggu jalan nafas. ${ }^{24}$ Lesi umumnya terlokalisasi di daerah rongga mulut terutama pada mukosa pipi, lidah, amandel, dan dinding faring bagian posterior. ${ }^{13,24}$

Antraks inhalasi merupakan bentuk antraks yang jarang terjadi tetapi mempunyai 
tingkat kematian tertinggi meskipun dilakukan pengobatan. ${ }^{24}$ Antraks inhalasi terjadi akibat menghirup udara yang mengandung spora antraks. ${ }^{24}$ Masa inkubasi antraks inhalasi yaitu 1-5 hari dengan gejala demam dan kedinginan/menggigil, ketidaknyamanan di dada, nafas pendek, pusing, batuk, mual, muntah, perut sakit, berkeringat, dan kelelahan ekstrim, serta tubuh terasa pegal. ${ }^{24}$ Pada fase akut terjadi gangguan pernafasan berat, takikardia, diaphoresis, stridor, dan sianosis yang diikuti septikemia fatal dan syok selama 1-2 hari. ${ }^{13,24}$ Penyebaran secara hematogenik B. anthracis dari infeksi inhalasi juga dapat mengakibatkan lesi pada sistem pencernaan. ${ }^{29}$

Antraks meningitis dan sepsis jarang teramati pada penderita antrak kutaneus tetapi umum terjadi pada penderita antraks gastrointestinal atau inhalasi. ${ }^{14,24}$ Antraks meningitis dan sepsis terjadi dikarenakan adanya penyebaran secara limfohematogenik B. anthracis dari lesi primer. ${ }^{36}$ Gejala antraks meningitis yaitu demam, sakit kepala berat, kejang, penurunan kesadaran, kaku duduk, dan diikuti dengan peningkatan tekanan serta adanya darah pada cairan cerebrospinal yang menyebabkan dalam waktu kurang dari 24 jam dapat mengalami hilang kesadaran dan meninggal, ${ }^{13,24}$ sedangkan gejala klinis antraks sepsis ditandai dengan demam, gangguan pernafasan, perubahan kondisi mental, dan toksemia, selain itu, syok parah dapat terjadi dan menyebabkan kematian dalam waktu singkat. ${ }^{14}$

Antraks injeksi merupakan hasil dari inokulasi B. anthracis pada subkutaneus. ${ }^{29}$ Antraks injeksi (suntik) merupakan bentuk klinis antraks baru yang dapat menyebabkan toksemia, sepsis, dan meningitis pada pengguna obat (heroin injeksi). ${ }^{34}$ Antraks injeksi ditandai dengan gejala klinis yang mirip dengan antraks kutaneus tetapi bisa lebih ke dalam lapisan kulit atau otot tergantung tempat injeksi dan tidak menyebabkan bekas luka/ eskar yang khas seperti pada antraks kutaneus. ${ }^{3,29,34}$ Gejala yang umum terjadi adalah pembengkakan jaringan lunak yang luas atau edema di daerah suntikan tanpa disertai rasa sakit dan pembentukan abses, gejala sistemik yang dapat terjadi yaitu sepsis, disfungsi organ, dan syok. ${ }^{14}$ Antraks injeksi dapat menyebar cepat dalam tubuh dan sulit untuk dikenali dan diobati. ${ }^{34}$ Kematian terjadi pada $34 \%$ pasien yang menjalani pengobatan. ${ }^{3,34}$

Edema Toxin (EdTx) dan Lethal Toxin (LeTx) yang dihasilkan B. anthrachis dapat merusak sistem kekebalan tubuh bawaan maupun adaptif. ${ }^{35}$ Toksin B. antrachis dapat masuk ke dalam sitoplasma beberapa jenis sel termasuk sel imun, EdTx akan meningkatkan cyclic AMP (cAMP) intrasel yang menyebabkan gangguan homeostasis air dan edema. ${ }^{15}$ Edema Toxin juga dapat menghambat aktivitas makrofag dengan memodifikasi produksi sitokin yang menyebabkan penurunan sirkulasi limfosit dan penurunan fungsi neutrofil. ${ }^{14}$ Lethal Toxin akan memotong N-terminal dari enzim mitogenactivated kinase kinases (MAPKKs atau MEKs) dan mengganggu jalur sinyal yang penting dalam regulasi sel, proliferasi, dan pertahanan stres seluler. ${ }^{15,35}$ Selain itu, LeTx juga dapat mengganggu atau mematikan produksi dan fungsi makrofag, sel dendritik, neutrofil, beberapa epitel, dan sel endotelial serta menurunkan regulasi produksi sitokin, menghambat induksi kemokin antimikrobia, menghambat proliferasi sel $\mathrm{B}$, dan produksi imunoglobulin. ${ }^{14}$

Tingkat keparahan infeksi antraks tergantung dari jumlah bakteri yang menginfeksi, tingkat virulensi bakteri, kondisi imunitas bawaan (innate) dan imunitas spesifik individu. ${ }^{14}$ Dosis infeksi antraks pada manusia belum jelas diketahui tetapi diperkirakan diantara 8.000-10.000 spora berdasarkan data nilai LD50 inhalasi pada primata nonmanusia $\left(2,5 \times 10^{2}-8 \times 10^{6}\right.$ spora $)$ dan data lainnya. ${ }^{14}$ Menurut Savransky et al, dosis infektif 50\% (ID50) tanpa adanya lesi kulit berada dalam rentang ribuan sampai puluhan ribu spora. ${ }^{15}$ Infektivitas dosis juga dipengaruhi oleh riwayat penyakit dan kekebalan tubuh individu yang terpapar. ${ }^{14}$ Risiko infeksi berkurang dengan penggunaan 
pakaian yang sesuai, sarung tangan, penutup luka, dan perilaku higienis lainnya. ${ }^{14}$

Centers for Disease Control and Prevention (CDC) menerbitkan rekomendasi pengobatan antraks dan profilaksis pasca pajanan setelah terjadinya insiden antraks selama tahun 2001 yaitu menggunakan obat antimikrobia (antibiotik) seperti amoxicillin, ciprofloxacin, doxycycline, levofloxacin, dan penicillin. ${ }^{37}$ Isolat klinis $B$. antrachis dari manusia secara in vitro juga sensitif terhadap berbagai antibiotik seperti aminoglycosides, macrolides, quinolones, carbapenems, tetracyclines, vankomycin, clindamycin, rifampin, clarithromycin, chloramphenicol, mefazoline, dan linezolid..$^{13,14,24}$ Antibiotik hanya efektif terhadap $B$. anthracis vegetatif dan tidak untuk spora. ${ }^{29}$ Menurut Clarasinta dan Soleha, pengobatan antraks pada manusia umumnya menggunakan terapi antibiotik penicillin. ${ }^{24}$ Pengobatan pada antraks kutaneus menggunakan procaine penicilin $2 \times 1,2$ juta IU yang diberikan secara intramuscular (IM) selama 5-7 hari atau dapat menggunakan benzyl penicilin 2500 IU secara IM setiap 6 jam, ciprofloxacin (500 mg) 2 kali sehari, doxycycline $(100 \mathrm{mg}) 2$ kali sehari, atau amoxicillin $(500 \mathrm{mg}) 3$ kali sehari. ${ }^{24}$ Pada antraks gastrointestinal dilakukan dengan penicillin G 18-24 juta IU/hari atau tetracyclines 1 gram/hari, selain itu juga dapat menggunakan chloramphenicol 6 gram/hari selama 5 hari diteruskan 4 gram/hari selama
18 hari dan dilanjutkan dengan erythromicin 4 gram/hari untuk menghindari supresi sumsum tulang. ${ }^{24}$ Pada antraks inhalasi pengobatan dilakukan dengan ciprofloxacin $400 \mathrm{mg}$ atau doxycycline $100 \mathrm{mg}$ intravena (IV) 2 kali sehari ditambah 1 atau 2 antibiotik lain kemudian dilanjutkan pengobatan oral (jika sesuai secara klinis) menggunakan ciprofloxacin $500 \mathrm{mg}$ atau doxycycline 100 mg 2 kali sehari untuk melengkapi 60 hari karena spora dimungkinkan dorman di paruparu dan bergerminasi seiring waktu. ${ }^{24,29}$ Beberapa vaksin antraks untuk manusia sudah dilisensikan dan digunakan di beberapa negara seperti BioThrax ${ }^{\circledR}$ atau Anthrax Vaccine Adsorbed (AVA) dan Anthrax Vaccine Precipitated (AVP). ${ }^{31}$ Vaksin tersebut umumnya merupakan kombinasi antibiotik dan antitoksin. ${ }^{31}$

\section{Prevalensi Antraks pada Manusia di Indonesia}

Antraks merupakan penyakit yang tersebar di seluruh dunia dan bersifat endemik di beberapa negara termasuk Indonesia., ${ }^{2,8,9}$ Sebanyak 14 provinsi di Indonesia dinyatakan sebagai daerah endemik antraks yaitu DKI Jakarta, Jawa Barat, Jawa Tengah, DI Yogyakarta, Jawa Timur, Nusa Tenggara Barat (NTB), Nusa Tenggara Timur (NTT), Sumatera Barat, Jambi, Sulawesi Tengah, Sulawesi Barat, Sulawesi Tenggara, Sulawesi Selatan, dan Gorontalo. ${ }^{12,13,24}$ 

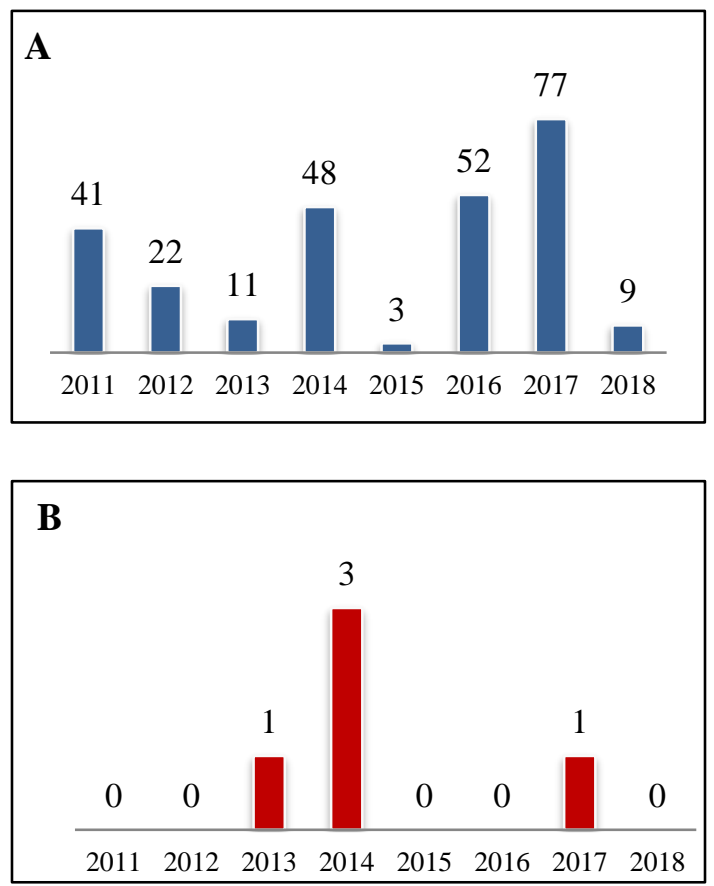

Gambar 1. Kejadian Kasus Antraks pada Manusia di Indonesia Tahun 2011-2018, (A) Jumlah Kasus; (B) Jumlah Kematian ${ }^{39}$

Kejadian kasus antraks pada manusia di Indonesia selama tahun 2011-2018 bersifat fluktuatif (Gambar 1). Pada tahun 2011 dan 2012 terjadi kasus antraks pada manusia dengan jumlah 63 tanpa kasus kematian, sedangkan pada tahun 2013 terjadi 11 kasus dengan satu kematian dan pada tahun 2014 sebanyak 48 kasus dengan tiga kematian. Selama tahun 2015-2016 terjadi total kasus sebanyak 55 kasus antraks manusia tanpa kasus kematian. ${ }^{38}$ Kejadian antraks pada manusia di Indonesia (2010-2016) sebagian besar merupakan antraks kutaneus (97\%) sedangkan 3\% lainnya merupakan antraks gastrointestinal. ${ }^{2}$ Selain itu sebagian besar penderita merupakan laki-laki $(61 \%)$ dan berumur > 15 tahun $(93 \%) .{ }^{2}$ Pada tahun 2017 total sebanyak 77 kasus antraks pada manusia dilaporkan kasus tersebut tersebar di lima provinsi yaitu DI Yogyakarta sebanyak empat kasus dengan satu kasus meninggal, Jawa Timur sebanyak 25 kasus, NTT sebanyak satu kasus, Sulawesi Selatan sebanyak dua kasus dan Gorontalo sebanyak 45 kasus (CFR 1,59\%). ${ }^{38,39}$ Pada tahun 2018, sebanyak sembilan kasus antraks pada manusia dilaporkan dengan persebaran delapan kasus di Jawa Timur dan satu kasus di Sulawesi Selatan. ${ }^{39}$ Provinsi lain tidak lagi ditemukan kasus antraks pada manusia akan tetapi masih merupakan daerah endemis antraks yang berpotensi menyebabkan kasus pada manusia jika tidak dilakukan pengendalian pada sektor kesehatan manusia maupun hewan. ${ }^{39}$

\section{Pencegahan dan Pengendalian Antraks}

Penularan antraks dari hewan ke manusia pada suatu daerah selain dipengaruhi faktor eko-lingkungan juga dipengaruhi oleh faktor sosial dan beberapa perilaku masyarakat. ${ }^{11}$ Perilaku masyarakat yang meningkatkan peluang terjadinya infeksi antraks pada manusia antara lain mengonsumsi atau menjual daging hewan terinfeksi yang mati dan atau menggunakan produk dari hewan tersebut. ${ }^{11,40}$ Hal tersebut umumnya dilatarbelakangi oleh kurangnya pengetahuan masyarakat, budaya di masyarakat, kemiskinan, dan masalah ekonomi. ${ }^{11}$ Oleh karena itu, masyarakat harus mewaspadai jika terjadi kasus ternak mati mendadak atau menunjukkan gejala ternak terinfeksi antraks 
yaitu penggembungan atau pembengkakan badan, suhu tubuh tinggi, kejang, leher bengkak, lemah otot, pendarahan (berwarna merah kehitaman) yang keluar dari telinga, hidung, anus, kelamin, serta hilangnya nafsu makan. ${ }^{41}$ Sapi yang menunjukkan gejala tersebut harus segera dilakukan karantina dan diobati dengan penisilin dosis tinggi selama 45 hari. ${ }^{41,42}$ Bangkai ternak yang mati harus segera dibakar (tanpa penyembelihan) atau dikubur dengan kedalaman minimal 2 meter disertai dengan proses disinfeksi di sekitar area penguburan untuk meminimalisir penyebaran bakteri antraks dari bangkai tersebut. ${ }^{9,32}$ Meskipun demikian, mengubur bangkai sebenarnya tidak mencegah infeksi inang baru di masa mendatang. ${ }^{27}$ Penguburan dangkal (kurang dari 2 meter) justru akan menyebabkan kontaminasi jangka panjang dan dapat menjadi hotspot infeksi baru di masa depan. ${ }^{27}$ Bencana alam seperti hujan lebat, banjir, longsor, dan gempa bumi dapat menyebabkan spora antraks muncul ke permukaan yang memperbesar potensi infeksi pada hewan herbivora. ${ }^{22,43}$ Pencegahan infeksi dapat dilakukan dengan menghindari daerah yang kemungkinan terkontaminasi spora antraks. ${ }^{27,41}$

Peranan serangga sebagai vektor penyebaran $B$. antrachis antar hewan telah diketahui, sehingga gigitan serangga (seperti biting flies) kemungkinan juga bisa menjadi jalur penularan antraks ke manusia melalui transfer mekanik. ${ }^{5,14}$ Hewan pemakan bangkai dan serangga necrophagous juga diduga berkontribusi dalam penyebaran spora antraks dan siklus infeksi selanjutnya. ${ }^{27}$ Serangga Chrysomya sp. (blowflies) dapat memakan bangkai dan mendepositkan feses yang mengandung spora pada tumbuhan. ${ }^{27}$ Oleh karena itu, pengendalian serangga yang bersifat necrophagous terutama di daerah endemik antraks perlu dilakukan untuk meminimalisir penyebaran antraks ke manusia.

Upaya pencegahan penyebaran antraks dapat dilakukan antara lain dengan melakukan vaksinasi ternak secara rutin setiap tahun atau sesuai rekomendasi instansi berwenang, menghindari kontak langsung dengan hewan yang dicurigai terinfeksi antraks, mematuhi Standard Operational Procedure (SOP) dan aturan dari instansi berwenang jika akan menambah jumlah ternak baru, memasak daging hingga matang sempurna, melaporkan kepada petugas kesehatan apabila menjumpai daging yang berlendir, berbau, dan berwarna kusam, memisahkan ternak yang sakit dengan ternak yang sehat, tidak melakukan autopsi atau pembedahan pada bangkai hewan yang mati akibat antraks, dan hewan yang mati tersebut harus dibakar atau dikubur yang dalam. ${ }^{12}$ Menurut Kementerian Kesehatan RI, beberapa upaya dapat dilakukan oleh masyarakat agar terhindar dari infeksi antraks yaitu membeli dan mengonsumsi daging yang disembelih di Rumah Potong Hewan (RPH) bersertifikat resmi, mengonsumsi daging hewan sehat dan dimasak matang sempurna, mencuci tangan dengan sabun antiseptik setelah mengolah dan memasak produk hewan. ${ }^{13}$ Masyarakat harus segera melaporkan ke petugas peternakan atau pusat kesehatan hewan jika menjumpai hewan ternak sakit atau mati mendadak. ${ }^{13}$ Selain itu, masyarakat tidak diperbolehkan membawa hewan sakit keluar wilayah agar penyakit tidak menyebar ke wilayah lain dan segera membersihkan diri dengan sabun atau disinfektan jika secara tidak sengaja melakukan kontak dengan hewan sakit atau mati. ${ }^{13}$ Masyarakat juga tidak diperbolehkan menyembelih atau mengonsumsi daging hewan sakit terutama jika hewan telah menunjukkan tanda terserang penyakit antraks. ${ }^{13}$ Masyarakat harus segera melapor dan memeriksakan diri ke puskesmas atau fasilitas kesehatan terdekat jika menemukan gejala antraks pada kulit yang khas yaitu bengkak kemerahan yang terasa gatal, panas, dan berwarna kehitaman di bagian tengah, mual, dan atau mengalami diare serta menceritakan riwayat sebelum sakit. ${ }^{13}$

Pondasi pengendalian antraks antara lain dengan vaksinasi ternak menggunakan bagian dari toksin bakteri yang telah dipurifikasi atau bakteri yang telah dimatikan. ${ }^{8,27}$ Vaksinasi terutama dilakukan di 
daerah endemik pada ternak yang rentan. ${ }^{32}$ Selain itu terapi antibiotik dapat diberikan pada tahap awal infeksi antraks. ${ }^{32}$ Respon cepat jika terjadi wabah, identifikasi serta perawatan yang cepat dan tepat pada hewan maupun manusia yang terinfeksi antraks juga diperlukan untuk meminimalisir akibat yang ditimbulkan serta membatasi kontaminasi lingkungan dan paparan pada manusia. ${ }^{2,6,8,21}$ Beberapa cara juga dapat dilakukan untuk menurunkan infeksi antraks pada hewan maupun manusia yaitu melakukan kerja multisektoral dan melibatkan peran serta pemerintah, memperkuat surveilans antraks pada hewan dan manusia, meningkatkan kapasitas petugas kesehatan dan laboratorium (terutama dalam kemampuan diagnosis, fasilitas, dan ketersediaan staf ahli), meningkatkan pengawasan dan pengelolaan agen biologis (termasuk perawatan medis, kontaminasi, dan dekontaminasi), mengembangkan strategi pengendalian, dan mendorong investigasi kolaboratif ketika terjadi wabah. ${ }^{8}$

Iklim merupakan salah satu faktor utama terjadinya wabah antraks. ${ }^{17}$ Beberapa penelitian dapat menggambarkan distribusi spasial B. antrachis di seluruh lanskap menggunakan ecological niche models yaitu dengan menghubungkan lokasi wabah dengan kondisi lingkungan (suhu, $\mathrm{pH}$ tanah, dan presipitasi) yang nonrandom menggunakan deskriptor multivarian. ${ }^{1}$ Faktor lingkungan juga dapat digunakan untuk memprediksi paparan dan risiko infeksi antraks di daerah tertentu, variabel seperti suhu, kelembaban, dan $\mathrm{pH}$ dapat dimasukkan ke aplikasi SIG (Sistem Informasi Geografis) untuk memetakan kesesuaian lingkungan yang menentukan kelangsungan spora antraks dan memprediksi wabah serta mengidentifikasi hotspot dalam studi di suatu daerah. ${ }^{2}$ Selain itu analisis SIG juga dapat digunakan sebagai sarana pengendalian antraks berbasis kewilayahan dengan mengidentifikasi daerah berisiko antraks. ${ }^{2,43}$. Ecological Niche Models (ENMs) dapat digunakan untuk memprediksi kondisi geografis atau lingkungan yang mendukung persistensi pathogen dan terjadinya wabah termasuk bakteri antraks. ${ }^{44}$ Pendekatan ENMs pernah digunakan untuk memprediksi potensi distribusi B. antrachis di lingkungan yang diintepretasikan sebagai landscape yang dilengkapi dengan kondisi biotik dan abiotik yang mendukung bakteri tersebut. ${ }^{44}$

Peningkatan kesadaran masyarakat terutama mengenai dampak penyakit antraks dengan metode yang mudah dipahami dan peningkatkan sistem pelaporan kasus oleh petugas juga berperan besar dalam pemberantasan antraks. ${ }^{20}$ Penyuluhan dapat dilakukan sebagai salah satu upaya meningkatkan kesadaran masyarakat (public awareness) dan sebaiknya didahului dengan survei pengetahuan, sikap, dan praktik untuk menilai persepsi masyarakat mengenai antraks. ${ }^{12}$ Selain itu, kesadaran institusi kesehatan masyarakat dalam pengawasan dan pemeriksaan ternak serta pengemasan produk ternak juga perlu ditingkatkan karena kesadaran yang rendah dapat meningkatkan risiko kontaminasi patogen pada makanan yang dapat membahayakan konsumen. ${ }^{12}$

\section{KESIMPULAN}

Antraks termasuk neglected zoonotic disease yang disebabkan bakteri $B$. antrachis. Spora B.antrachis resisten terhadap berbagai lingkungan ekstrim sehingga berpotensi menyebabkan wabah yang berulang. Antraks dapat menginfeksi ternak maupun manusia. Antraks pada manusia dapat dijumpai dalam 4 bentuk utama yaitu kutaneus, gastrointestinal, inhalasi, dan injeksi, sepsis dan meningitis dapat terjadi akibat infeksi sistemik yang fatal. Pengobatan antraks dilakukan dengan terapi antibiotik. Prevalensi antraks pada manusia di Indonesia bersifat fluktuatif dan sebagian besar merupakan antraks kutaneus. Pencegahan dan pengendalian antraks dapat dilakukan terutama dengan vaksinasi, mematuhi SOP dan aturan dari pemerintah atau instansi berwenang, memperkuat surveilans antraks pada hewan maupun manusia, meningkatkan kapasitas SDM dan 
prasarana diagnosis, meningkatkan pengetahuan dan kesadaran masyarakat, serta kerjasama multisektor.

\section{KONTRIBUSI PENULIS}

Kontribusi setiap penulis dalam artikel ini adalah IZRS sebagai kontributor utama yang bertanggung jawab dalam konsep penulisan artikel secara menyeluruh. SA sebagai kontributor anggota bertanggung jawab dalam membantu penelusuran literatur.

\section{DAFTAR PUSTAKA}

1. Blackburn JK, Odugbo MO, Van Ert $M$, O'Shea B, Mullins J, Perrenten V, et al. Bacillus anthracis diversity and geographic potential across Nigeria, Cameroon and Chad: further support of a Novel West African Lineage. PLoS Neg1 Trop Dis. 2015;9(8):1-14. doi:10.1371/journal.pntd.0003931.

2. Abawi I, Fibriana AI. Analisis spasial faktor lingkungan fisik daerah endemik antraks. HIGEIA. 2019;3(2):190-201.

3. Olani A, Dawo F, Lakew M. Laboratory diagnostic methods and reported outbreaks of anthrax in Ethiopia. European Journal of Biological Research. 2020;10(2):81-95.

4. Yu D, He J, Zhang E, Wang P, Liu D, Hou Y, et al. Investigation and source-tracing of an anthrax outbreak in Gansu Province, China. PLoS One. 2018;13(8):1-9.

5. Barro AS, Fegan M, Moloney B, Porter K, Muller J, Warner S, et al. Redefining the Australian anthrax belt: modeling the ecological niche and predicting the geographic distribution of Bacillus anthracis. PLoS Negl Trop Dis. 2016;10(6):e0004689. doi:10.1371/journal.pntd.0004689.

6. Yadeta W, Giro A, Amajo M, Jilo K. Recent understanding of the epidemiology of animal and human anthrax in Ethiopia with emphasis on diagnosis, control and prevention interventions-review. World Journal of Medical Sciences. 2020;17(1):1-9. doi:10.5829/idosi.wjms.2020.01.09.

7. Salsabila DA, Sunarno. Identifikasi agen penyakit anthrax pada sediaan apus darah sapi potong di Surakarta. E-journal Binawakya. 2019;14(3):2291-8.

8. Vieira AR, Salzer JS, Traxler RM, Hendrick
KA, Kadzik ME, Marston CK, et al. Enhancing surveillance and diagnostics in anthrax-endemic countries. Emerg Infect Dis. 2017;23(13):S147-53. doi:10.3201/eid2313.170431.

9. Mwakapeje ER, Høgset S, Fyumagwa R, Nonga HE, Mdegela RH, Skjerve E. Anthrax outbreaks in the humans - livestock and wildlife interface areas of Northern Tanzania: a retrospective record review 2006-2016. BMC Public Health. 2018;18(106):1-11. doi:10.1186/s12889-017-5007-z.

10. Basri C, Dwidzuriputra S, Sudarnika E. Factors influencing farmers participation in the vaccination program against Anthrax in Bogor District, Indonesia. Acta Vet Indones. 2019; (December):29-34. doi:10.29244/avi.0.0.29-34.

11. Sitali DC, Mumba C, Skjerve E, Mweembe O, Kabonesa C, Mwinyi MO, et al. Awareness and attitudes towards anthrax and meat consumption practices among affected communities in Zambia: A mixed methods approach. PLoS Negl Trop Dis. 2017;11(5):118. doi:10.1371/journal.pntd.0005580.

12. Martindah E. Faktor risiko, sikap dan pengetahuan masyarakat peternak dalam pengendalian penyakit antraks. WARTAZOA. 2017;27(3):135-44. doi:10.14334/wartazoa.v27i3.1689.

13. Direktorat Jenderal Pencegahan dan Pengendalian Penyakit. Surat edaran tentang waspada penyakit antraks. Jakarta: Kementerian Kesehatan Republik Indonesia; 2017. 1-2.

14. Doganay M, Demiraslan H. Human anthrax as a re-emerging disease. Recent Pat Antiinfect Drug Discov. 2015;10(1):10-29. doi:10.2174/1574891x10666150408162354.

15. Savransky V, Ionin B, Reece J. Current status and trends in prophylaxis and management of anthrax disease. Pathogens. 2020;9(5):370. doi:10.3390/pathogens9050370.

16. Kementerian Kesehatan Republik Indonesia. Antraks di Yogyakarta sudah teratasi [Internet]; 2017 [Updated 2017 January 25; Cited 2020 May 28]. Available from: http://www.depkes.go.id.

17. Liu Y, Li Y, Wang Q, Fu J, Ji F. Sporadic human cutaneous anthrax outbreak in Shaanxi Province, China: report of two cases from 
2018. Brazilian J Infect Dis. 2020;24(1):81-4. doi:10.1016/j.bjid.2019.12.002.

18. Muturi M, Gachohi J, Mwatondo A, Lekolool I, Gakuya F, Bett A, et al. Recurrent anthrax outbreaks in humans, livestock, and wildlife in the same locality, Kenya, 2014-2017. Am J Trop Med Hyg. 2018;99(4):833-9. doi:10.4269/ajtmh.18-0224.

19. Nakanwagi M, Ario AR, Kwagonza L, Aceng FL, Mwesigye J, Bulage L, et al. Outbreak of gastrointestinal anthrax following eating beef of suspicious origin: Isingiro District, Uganda, 2017. PLoS Negl Trop Dis. 2020;14(2):1-12. doi:10.1371/journal.pntd.0008026.

20. Bagenda I, Dariani W, Yudianingtyas DW. Investigasi outbreak penyakit antraks di Kabupaten Polewali Mandar Tahun 2016. Proc. of the $20^{\text {th }}$ FAVA CONGRESS\& the $15^{\text {th }}$ KIVNAS PDHI; 2018 Nov 1-3; Bali. Bogor: IPB; 2018.

21. Mwakapeje ER, Høgset S, Softic A, Mghamba J, Nonga HE, Mdegela RH, et al. Risk factors for human cutaneous anthrax outbreaks in the hotspot districts of Northern Tanzania: an unmatched case-control study. R Soc Open Sci. 2018;5(9):1-13. doi:10.1098/rsos.180479.

22. Kutmanova A, Doganay M, Zholdoshev S. Human anthrax in Kyrgyz Republic: epidemiology and clinical features. J Infect Public Health. 2020;13(8):1161-5. doi:10.1016/j.jiph.2020.02.043.

23. Chen WJ, Lai SJ, Yang Y, Liu K, Li XL, Yao $\mathrm{HW}$, et al. Mapping the distribution of anthrax in Mainland China, 2005-2013. PLoS Negl Trop Dis. 2016;10(4):1-15. doi:10.1371/journal.pntd.0004637.

24. Clarasinta C, Soleha TU. Penyakit antraks: ancaman untuk petani dan peternak. Majority. 2017;7(1):158-64.

25. Goel AK. Anthrax: a disease of biowarfare and public health importance. World J Clin Cases. 2015;3(1):20-33. doi:10.12998/wjcc.v3.i1.20.

26. Perry MR, Ionin B, Barnewall RE, Vassar ML, Reece JJ, Park S, et al. Development of a guinea pig inhalational anthrax model for evaluation of post-exposure prophylaxis efficacy of anthrax vaccines. Vaccine. 2020;38(10):2307-14. doi:10.1016/j.vaccine.2020.01.068.

27. Hueffer K, Drown D, Romanovsky V,
Hennessy T. Factors contributing to anthrax outbreaks in the Circumpolar North. Ecohealth. 2020;17(1):174-80. doi:10.1007/s10393-020-01474-z.

28. Kim J, Gedi V, Lee SC, Cho JH, Moon JY, Yoon MY. Advances in anthrax detection: overview of bioprobes and biosensors. Appl Biochem Biotechnol. 2015;176:957-77. doi:10.1007/s12010-015-1625-z.

29. Spickler AR. Anthrax [Internet]. The Center for Food Security \& Public Health IOWA State University of Science and Technology; 2017 [Updated 2017 December; Cited 2020 July 17]. Available from:http://www.cfsph.iastate.edu/DiseaseInfo /factsheets.php.

30. Sudarmono PP. Biosecurity dalam kedokteran dan kesehatan. eJournal Kedokt Indones. 2015;3(1):1-7. doi:10.23886/ejki.3.4800.

31. Clark A, Wolfe DN. Current state of anthrax vaccines and key r\&d gaps moving forward. Microorganisms. 2020;8(5):651. doi:10.3390/microorganisms8050651.

32. Lepheana RJ, Oguttu JW, Qekwana DN. Temporal patterns of anthrax outbreaks among livestock in Lesotho, 2005-2016. PLoS One. 2018;13(10):e0204758. doi:10.1371/journal.pone.0204758.

33. Kasradze A, Echeverria D, Zakhashvili K, Bautista C, Heyer N, Imnadze P, et al. Rates and risk factors for human cutaneous anthrax in the country of Georgia: national surveillance data, 2008-2015. PLoS One. 2018;13(2):1-9. doi:10.1371/journal.pone.0192031.

34. Centers for Disease Control and Prevention. Guide to understanding anthrax infectious disease-anthrax [Internet]; 2016 [Updated 2016 May; Cited 2020 May 25]. 1-9. Available from: http://www.cdc.gov.

35. Dumas EK, Demiraslan H, Ingram RJ, Spark RM, Muns E, Zamora A, et al. Toxinneutralizing antibodies elicited by naturally acquired cutaneous anthrax are elevated following severe disease and appear to target conformational epitopes. PLoS One. 2020;15(4):1-17. doi:10.1371/journal.pone.0230782.

36. Kansas Department of Health and Environment. Anthrax investigation guideline [Internet]; 2018 [Updated 2018 January 1; Cited 2020 July 16]. 1-20. Available 
from://www.kdheks.gov.

37. McLaughlin HP, Bugrysheva JV, Conley AB, Gulvik CA, Cherney B, Kolton CB, et al. Rapid nanopore whole-genome sequencing for anthrax emergency preparedness. Emerg Infect Dis. 2020;26(2):358-61. doi:10.3201/eid2602.191351.

38. Kementerian Kesehatan Republik Indonesia. Profil Kesehatan Indonesia Tahun 2017. Jakarta: Kementerian Kesehatan RI; 2018. 1496.

39. Kementerian Kesehatan Republik Indonesia. Profil Kesehatan Indonesia Tahun 2018. Jakarta: Kementerian Kesehatan RI; 2019. 1556.

40. Makhija S, Sumit K, Hossain S. Risk factor associated with anthrax transmission among the Tribal Communities of Odisha. Indian Journal of Public Health Research\& Development. 2020;11(1):603-8.
41. Winarsih WH. Penyakit ternak yang perlu diwaspadai terkait keamanan pangan. Cakrawala. 2018;12(2):208-21. doi:10.32781/cakrawala.v12i2.270.

42. Direktorat Jenderal Peternakan dan Kesehatan Hewan. Pedoman pengendalian dan pemberantasan penyakit hewan menular (PHM) - seri penyakit antraks. Jakarta: Kementerian Pertanian Republik Indonesia; 2016: 1-46.

43. Ghaderi E, Mohsenpour B, Moradi G, Karimi M, Najafi F, Nili S, et al. Spatial distribution of cutaneous anthrax in western Iran from 2009 to 2016: geographic information system mapping for predicting risk of anthrax outbreaks. Asian Pac J Trop Med. 2020;13(5):227-34. doi:10.4103/1995-7645.283516.

44. Morris LR, Blackburn JK. Predicting disease risk, identifying stakeholders, and informing control strategies : a case study of anthrax in Montana. Ecohealth. 2016;13(2):262-73. doi:10.1007/s10393-016-1119-7. 